
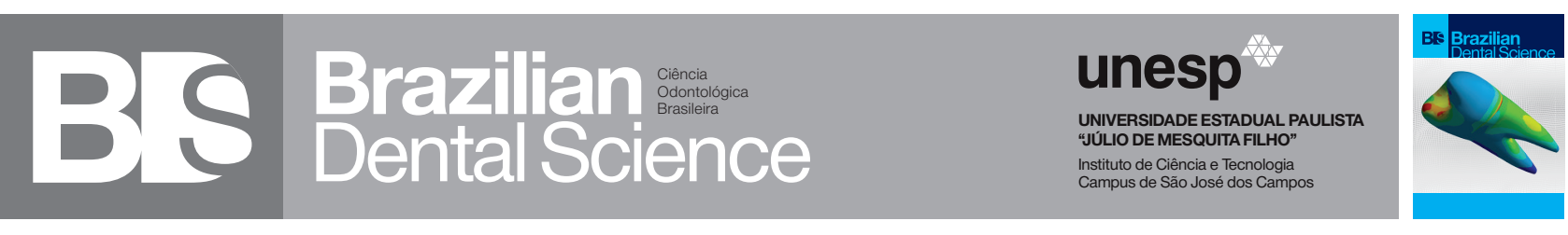

\title{
Chitosan in different concentrations added to a two-step etch-and-rinse adhesive system: influence on bond strength to dentin
}

Quitosana em diferentes concentrações adicionada a um sistema adesivo convencional de dois passos: influência na resistência de união à dentina

Rafael Avellar de Carvalho NUNES ${ }^{1}$, Flávia Lucisano Botelho do AMARAL ${ }^{1}$, Fabiana Mantovani Gomes FRANÇA ${ }^{1}$, Cecilia Pedroso TURSSI ${ }^{1}$, Roberta Tarkany BASTING ${ }^{1}$

1 - São Leopoldo Mandic Institute and Dental Research Center - Campinas - SP - Brazil.

\begin{abstract}
Objectives: the aim of the present study was to evaluate the influence of adding different concentrations of chitosan to an experimental two-step etch-and-rinse adhesive system on the bond strength and failure mode to dentin. Material and Methods: thirty-two flat dentin surfaces were obtained from extracted human third molars and divided into four groups $(n=8)$ for application of the adhesive systems: $\mathrm{AD}$ - conventional two-step adhesive system (Adper Single Bond 2); EXP - experimental two-step etch-and-rinse adhesive system; Chi0.2\% - EXP with addition of $0.2 \%$ Chitosan; Chi0.5\% - EXP with addition of 0.5\% Chitosan. Resin composite build-ups were made and the composite/ dentin specimens were sectioned to obtain rectangular beams with a bond area of approximately $1 \mathrm{~mm}^{2}$. After 24 hours, the sticks were submitted to microtensile bond strength tests in a universal test machine. The fracture pattern was evaluated under a stereoscopic loupe at 40X magnification. Results: one-way analysis of variance showed that the type of adhesive system had no significant effect on the bond strength values ( $\mathrm{p}=0.142)$, showing the mean bond strength values (standard deviation), in $\mathrm{MPa}$, for the groups as follows: $\mathrm{AD}=20.1$ (5.4); $\mathrm{EXP}=16.6$ (2.3); Chi0.2\%=16.1 (2.8); Chio. $\%=16.9$ (2.3). In all the groups there was predominance of cohesive fractures in dentin, representing 68 to $82 \%$ of the failure modes. Conclusion: the addition of 0.2 or $0.5 \%$ of chitosan had no influence on the bond strength and failure mode of an experimental two-step etch-andrinse adhesive system to dentin.
\end{abstract}

\section{KEYWORDS}

Chitosan; Dental adhesives; Failure mode; Microtensile bond strength.

\section{RESUMO}

Objetivo: o objetivo deste estudo foi avaliar a influência da incorporação de diferentes concentrações de quitosana em um sistema adesivo experimental convencional de dois passos na resistência de união à dentina e modo de falha. Material e Métodos: trinta e duas superfícies de dentina planificadas foram obtidas de terceiros molares e separadas em quatro grupos $(n=8)$ para aplicação dos sistemas adesivos: $A D$ sistema adesivo convencional de dois passos (Adper Single Bond 2); EXP - sistema adesivo convencional de dois passos experimental; Chi0,2\% - EXP com incorporação de quitosana a 0,2\%; Chi0,5\% - EXP com incorporação de quitosana a 0,5\%. Blocos de resina composta foram confeccionados e os espécimes de resina composte/ dentina foram seccionados para se obter palitos retangulares com interface adesiva foi seccionada para obtenção de palitos com área de união de aproximadamente $1 \mathrm{~mm}^{2}$. Após 24 horas, os palitos foram submetidos aos testes de resistência de união por microtração em máquina universal de ensaios. O modo de falha foi avaliada em lupa estereoscópica com aumento de 40 vezes. Resultados: análise de variância a um critério mostrou que o tipo de sistema adesivo não apresentou efeito significativo nos valores de resistência de união ( $\mathrm{p}=0,142)$, observando-se os respectivos valores de média (desvio-padrão), em MPa, para os grupos: $\mathrm{AD}=20,1$ (5,4); $\mathrm{EXP}=16,6$ (2,3); Chi0,2\%=16,1 (2,8); Chi0,5\%=16,9 $(2,3)$. Para todos os grupos houve predominância de fraturas coesivas em dentina, representando 68 a $82 \%$ dos modos de falhas. Conclusão: a incorporação de quitosana a 0,2 ou $0,5 \%$ na influenciou a resistência de união à dentina e o modo de falha de um sistema adesivo convencional de dois passos experimental à dentina.

\section{PALAVRAS-CHAVE}

Quitosana; Adesivos dentários; Modo de falha; Resistência de união por microtração. 


\section{INTRODUCTION}

$\mathrm{W}$ hen using adhesive systems, total-etch or self-etch approaches can be used to obtain bond strength to dentin: while totaletch adhesives require a separated etching step, self-etch adhesives contain acidic monomers that simultaneously demineralize and infiltrate dentin $[1,2]$. Although they are presented in different forms of bond to dentin strategies, the main constituents of adhesive systems are the methacrylate-based monomers, with the most commonly used type being those based on Bis-GMA (bisphenol glycidyl methacrylate), UDMA (urethane dimethacrylate), TEGDMA (triethylene glycol dimethcrylate) and HEMA (Hiydroxyethyl Methacrylate) [3-6].

The monomer Bis-GMA has hydrophobic characteristics making the hybrid layer less permeable, thereby increasing the bond strength of restorations and cementations $[1,5]$. However, it is never completely polymerized, with the presence of residual monomers being observed; and should these come into contact with the pulp when applied in deep cavities, they may cause genotoxic effects, promoting damage to DNA, genetic mutations and pulp complications [6-9].

With the purpose of preventing the passage of free monomers in the direction of the pulp, or to diminish the damage they cause, some components may be incorporated into the adhesive systems or restorative materials [6]. One of these components is chitosan, which is a hydrophilic biopolymer obtained from chitin, a polysaccharide existent in the shells of crustaceans and on the cell wall of fungi. It has the characteristics of biocompatibility and biodegradability, and is used as a biomaterial in the area of health $[6,10,11]$. Its activity is reported to be antimicrobial against bacteria; fungi and viruses; and anti-inflammatory [10-13], in addition to being capable of inhibiting the growth of Porphyromonas gingivalis (Pg) and Aggregatibacter actinomycetemcomitans [14,15]. Thus it is a very versatile polymer that is easily modifiable to improve the use of its biological and physical-chemical properties [10].

In dentistry, chitosan has been used in the form of gel, obtained from different granulations and concentrations of the powder of this biomaterial; in surgical sites, or in nonsurgical periodontal therapy [12], as well as for the control of periodontal pathogens and in the response of fibroblasts to inflammatory stimuli [12]. Chitosan may be incorporated into different types of restorative materials such as glass ionomer in concentrations from 5 to $50 \%$ and in adhesive systems in concentrations from 0.12 to $1 \%[6,16-$ $18]$ to diminish or avoid cell damage when applied in deep cavities. Due to the mean diameter of human dentin tubules being from 1 to $3 \mu \mathrm{m}$, in situations where there are unreacted free monomers [19], it is possible for them to pass through the tubules in the direction of dental pulp [6]. However, in adhesives containing chitosan, their free molecules also pass through the dentinal tubules, thus generating protection of the pulp cells; or it is possible for them to link to the monomers of methacrylate, thereby blocking or reducing their passage up to the pulp $[6,19]$. Better sealing of dentinal tubules by the chitosan molecules has also been observed when an adhesive system into which chitosan has been incorporated was applied, thus making it difficult for monomers from the adhesive systems to pass in the direction towards the pulp cells [20].

Into conventional adhesives, Elsaka [21] incorporated different concentrations $(0.12 \%$, $0.25 \%, 0.5 \%$ and $1 \%$ ), and observed that the concentrations of 0.12 and $0.25 \%$ had no influence on the bond strength values, but higher concentrations led to reduction in the values. When using the concentration of $1 \%$ added to the conventional two-step adhesive systems, Diolosà et al. [22] observed that the immediate bond strength did not differ between the control and experimental groups with chitosan incorporated; however, after performing thermal cycling, significant reduction in the bond strength values was observed in the control group, and in the bond stability of the adhesive with the incorporation of chitosan. 
Szczepanska et al. [6] verified that low concentrations of chitosan (up to $0.5 \%$ ) promoted protection of the pulp cells. On the other hand, chitosan compromised the bond strength to dentin when the experimental two-step adhesive system was used [21]. However, further studies are necessary to investigate the influence of adding chitosan in different concentrations $(0.2$ and $0.5 \%$ ) to experimental conventional twostep adhesive systems with regards to bond strength to dentin, and to make a comparative evaluation with a commercial adhesive system. Therefore, the null hypothesis tested was that different concentrations of chitosan added to an experimental conventional two-step adhesive system would not influence the bond strength to dentin and its failure mode when compared with a commercially available adhesive system.

\section{MATERIAL AND METHODS}

The experimental design was planned with the use of 32 dentin blocks obtained from 32 human third molars to consist the experimental units. Eight dentin blocks were allocated into four experimental groups $(n=8)$. The factor under study was "experimental treatments", in four levels: AD) commercial two-step etch-and-rinse adhesive system; EXP: experimental adhesive twostep etch-and-rinse system (composition similar to that of $\mathrm{AD}$ ); CHI0.2: experimental adhesive two-step etch-and-rinse system with addition of $0.2 \%$ chitosan; and CHI0.5: experimental adhesive two-step etch-and-rinse system with addition of $0.5 \%$ chitosan. The variable response were microtensile bond strength test and failure mode evaluation. The ISO/TS 11405 standard was followed to perform the micro tensile bond strength test.

\section{Materials}

The main materials used in this study are described in Table 1.

Table 1 - Specifications of materials used in research, Bis-GMA (bisphenol glycidyl methacrylate), TEGDMA (-triethylene glycol dimethacrylate) and HEMA (hydroxyethyl methacrylate)

\begin{tabular}{|c|c|c|c|}
\hline Material (Lot Number) & Classification & Composition & $\begin{array}{c}\text { Manufacturer } \\
\text { (City,State, Country) }\end{array}$ \\
\hline Total Etch (L42017) & Acid conditioner & $37 \%$ Phosphoric acid & $\begin{array}{l}\text { Ivoclar Vivadent (Ellwangen, } \\
\text { GERMANY) }\end{array}$ \\
\hline $\begin{array}{l}\text { Adper Single Bond2 } \\
\text { (N261545) }\end{array}$ & $\begin{array}{l}\text { Commercial two-step etch } \\
\text {-and-rinse adhesive system }\end{array}$ & $\begin{array}{c}\text { bisphenol A glycidyl methacrylate (Bis-GMA), silane- } \\
\text { treated silica, 2-hydroxyethyl methacrylate } \\
\text { (HEMA), glycerol 1,3-dimethacrylate, diurethane } \\
\text { dimethacrylate, copolymer of } \\
\text { acrylic and itaconic acids, ethyl alcohol }\end{array}$ & 3M /ESPE (St. Paul, MN, USA) \\
\hline $\begin{array}{l}\text { Experimental two-step etch } \\
\text {-and-rinse adhesive system }\end{array}$ & $\begin{array}{l}\text { Experimental two-step etch } \\
\text {-and-rinse adhesive system }\end{array}$ & $\begin{array}{l}55 \% \text { bisphenol A glycidyl methacrylate (Bis-GMA), } 45 \% \\
\text { 2-hydroxyethyl methacrylate (HEMA), } 0.7 \% \text { photoinitiater } \\
\text { (camphorquinone), } 0.7 \%, 2 \text {-(dimethylamino) ethyl metha- } \\
\text { crylate (DMAEMA), ethyl alcohol }\end{array}$ & $\begin{array}{l}\text { Sigma-Aldrich } ® \text {, (St. Louis, MO, } \\
\text { USA) }\end{array}$ \\
\hline $\begin{array}{l}\text { Experimental two-step etch } \\
\text {-and-rinse adhesive system } \\
\text { with addition of } 0.2 \% \text { chitosan. }\end{array}$ & $\begin{array}{l}\text { Experimental two-step etch } \\
\text {-and-rinse adhesive system } \\
\text { with chitosan }\end{array}$ & $\begin{array}{l}55 \% \text { bisphenol A glycidyl methacrylate (Bis-GMA), } 45 \% \\
\text { 2-hydroxyethyl methacrylate (HEMA), } 0.7 \% \text { photoinitiater } \\
\text { (camphorquinone), } 0.7 \%, 2 \text {-(dimethylamino) ethyl metha- } \\
\text { crylate (DMAEMA), ethyl alcohol, } 0.2 \% \text { chitosan. }\end{array}$ & $\begin{array}{l}\text { Sigma-Aldrich } ® \text {, (St. Louis, M0, } \\
\text { USA) }\end{array}$ \\
\hline $\begin{array}{l}\text { Experimental two-step etch } \\
\text {-and-rinse adhesive system } \\
\text { with addition of } 0.5 \% \text { chitosan. }\end{array}$ & $\begin{array}{l}\text { Experimental two-step etch } \\
\text {-and-rinse adhesive system } \\
\text { with chitosan }\end{array}$ & $\begin{array}{l}55 \% \text { bisphenol A glycidyl methacrylate (Bis-GMA), 45\% } \\
\text { 2-hydroxyethyl methacrylate (HEMA), ethanol, } 0.7 \% \\
\text { photoinitiater (camphorquinone), 0.7\%, 2-(dimethylami- } \\
\text { no) ethyl methacrylate (DMAEMA), ethyl alcohol, 0.5\% } \\
\text { chitosan. }\end{array}$ & $\begin{array}{l}\text { Sigma-Aldrich®, (St. Louis, MO, } \\
\text { USA) }\end{array}$ \\
\hline Filtek Z100 (N187347BR) & Microhybrid resin composite & $\begin{array}{c}\text { Microhybrid resin composite with organic matrix } \\
\text { bisphenol A glycidyl methacrylate (Bis-GMA), Trie- } \\
\text { thyleneglycol-dimethacrylate (TEGDMA) and inorga- } \\
\text { nic matrix Zirconium /Silica. }\end{array}$ & 3M /ESPE (St. Paul, MN, USA) \\
\hline
\end{tabular}




\section{Dentin sample preparation}

After the project was approved by the Ethics Committee (Process Number 559.670), 32 healthy human molars were used, cleaned and stored in an aqueous solution of Thymol $0.1 \%$ for a maximum period of three months.

To obtain a flat dentin surface, the occlusal enamel of the teeth was removed by using a diamond disc (UKAM Industrial Superhard Tools, Valencia, CA, USA) in a precision cutting machine (Isomet 1000, Buehler, Lake Bluff, IL, USA). After this, the surface was polished with a silicon carbide abrasive paper disc, with 600-grit and 1200-grit, in a metallographic polishing machine (Aropol $2 \mathrm{v}$, Arotec, Araçariguama, SP, Brazil) to obtain a standardized surface as regards smear layer.

The teeth were sectioned transversally $3 \mathrm{~mm}$ below the amelocement junction level, exposing the pulp chamber that was completely filled with resin composite (Filtek Z100, 3M ESPE, St. Paul, MN, USA) after cleaning the chamber and applying the adhesive system (Adper Single Bond 2, 3M ESPE, St. Paul, MN, USA). This procedure was performed to obtain longer stickers for the microtensile bond tests to be fixed in the acrylic device to not interfere in the bonded area.

\section{Randomization of samples into groups}

The teeth were divided into four groups $(n=8)$ according to the adhesive to be used:

G1) AD: commercial two-step etch-andrinse adhesive system (Adper Single Bond 2/ 3M ESPE, St. Paul, MN, USA)

G2) EXP: experimental two-step etch-andrinse adhesive system (composition similar to that of $\mathrm{AD}$ )

G3) CHIO.2: experimental two-step etchand-rinse adhesive system with addition of $0.2 \%$ chitosan.

G4) CHI0.5: experimental two-step etchand-rinse adhesive system with addition of $0.5 \%$ chitosan.

\section{Adhesive system preparation}

To prepare the experimental adhesive system (EXP, CHIO.2 and CHIO.5 groups), the components were weighted and mixed together under controlled temperature $\left(23^{\circ} \mathrm{C}\right)$ avoiding. For CHIO.2 and CHIO.5 groups, chitosan was incorporated under vigorous mixing in a vortex avoiding exposure to light.

\section{Bonding procedures}

For all groups, before application of the adhesive systems, phosphoric acid was applied for 15 seconds, and removed with jets of air/ water for 15 seconds, and gently drying the dentin with absorbent paper, leaving it slightly damp [23]. After this, a disposable microbrush was used to apply two consecutive coats of each adhesive according to the groups, followed by a light jet of air until the solvent was volatilized, and light activation for 10 secs with a halogen light appliance (LC, Demetron, Illinois USA) with minimum irradiance of $542 \mathrm{~mW} / \mathrm{cm} 2$ and maximum of $550 \mathrm{~mW} / \mathrm{cm} 2$.

Resin composite build-ups were made on the bonding surfaces with four increments of resin composite (Filtek Z100, 3M ESPE, St. Paul, MN, USA), with the first three increments being light activated for 20 seconds, and the last for 60 seconds.

Preparation of the beams for microtensile bond tests and failure mode analysis

After being kept at relative humidity in an oven at $37^{\circ} \mathrm{C}$ for 24 hours, the teeth were fixed onto acrylic plates with sticky wax, to be sectioned in a cutting machine (Isomet 1000, Buehler, Lake Bluff, IL, USA) to obtain sticks with a bond area of approximately $1.0 \mathrm{~mm} 2$ for microtensile testing. From each tooth, an average of 7 to 8 sticks were obtained.

For the test, the sticks were fixed to an acrylic device with cyanoacrylate adhesive, and submitted to a load of $50 \mathrm{~N}$ at a speed of $0.5 \mathrm{~mm} /$ minute until failure occurred. A universal test 
machine (DL2000, EMIC, São José dos Pinhais PR, Brazil) was used. The failures surfaces were evaluated under a stereoscopic loupe (EK3ST, Eikonal Equip. Opticos e Analíticos, São Paulo, SP, Brazil) at 40x magnification to determine the failure mode (adhesive, mixed, cohesive in dentin and cohesive in resin).

The mean values of the beams for each tooth were used to perform the microtensile bond strength analysis. The presuppositions of normality (Shapiro-Wilk test) and homoscedasticity (Levene test) were verified for datagathering purposes. Since the data presented normal distribution, the microtensile bond strength results were submitted to oneway analysis of variance (ANOVA) for repeated measures. These analyses were performed on SPSS 20 software (SPSS Inc., Chicago, IL, USA), at a significance level of $5 \%$. The failure mode was presented descriptively, based on the percentage of failures for each type.

\section{RESULTS}

One-way analysis of variance demonstrated that the type of adhesive system had no significant effect on the bond strength values $(\mathrm{p}=0.142)$ (Table 2). The main effect of addition of chitosan on microtensile bond strength was not significant, comparing groups Chi0.2\% and Chi0.5\% with their corresponding control EXP.

Table 2 - Means and standard deviation of bond strength values (MPa) according to treatment and type of adhesive system

\begin{tabular}{|c|c|}
\hline Type of adhesive system & Bond Strength \\
\hline AD & $20.1(5.4) \mathrm{A}$ \\
\hline EXP & $16.6(2.3) \mathrm{A}$ \\
\hline CHIO.2\% & $16.1(2.8) \mathrm{A}$ \\
\hline $\mathrm{CH} 0.5 \%$ & $16.9(2.3) \mathrm{A}$ \\
\hline
\end{tabular}

Means followed by same letters do not differ among them ( $p>0.05$ ).
Evaluation of the failure modes observed in the sticks obtained from the test specimens fabricated with the different adhesive systems revealed that in all the groups there was predominance of cohesive fractures in dentin that represented 68 to $82 \%$ of the failure modes (Table 3).

Table 3 - Relative frequency of failures, according to type of adhesive system

\begin{tabular}{|c|cccc|}
\hline & $\begin{array}{c}\text { Adhesive } \\
\text { Fracture }\end{array}$ & $\begin{array}{c}\text { Cohesive } \\
\text { fracture in } \\
\text { dentin }\end{array}$ & $\begin{array}{c}\text { Cohesive } \\
\text { fracture in } \\
\text { resin }\end{array}$ & $\begin{array}{c}\text { Mixed } \\
\text { fracture }\end{array}$ \\
\hline AD & $18 \%$ & $82 \%$ & - & - \\
\hline EXP & $9 \%$ & $71 \%$ & $14 \%$ & $6 \%$ \\
\hline CHI0.2\% & $8 \%$ & $75 \%$ & $11 \%$ & $6 \%$ \\
\hline CHI0.5\% & $16 \%$ & $68 \%$ & $16 \%$ & - \\
\hline
\end{tabular}

\section{DISCUSSION}

Different studies evaluated the inclusion of chitosan into different restorative materials, as resin cement modified [24] and glass ionomer cements [25]. When included into adhesive systems, it was demonstrated that the inclusion of low concentrations of chitosan ( 0.12 and $0.25 \%$ ) do not compromise of bond strength to dentin compared to a higher concentration (1\%) [21]. In the present study, low concentrations of chitosan $(0.2 \%$ and $0.5 \%)$ were used incorporated into a conventional two-step adhesive system because it is routinely used in clinical practice, and it presents good mechanical and physical properties [26-29]. The experimental adhesives (incorporated or not with chitosan) had similar composition as the commercial adhesive system used. The experimental adhesive system and the adhesive systems incorporated with chitosan were compared to a well-known commercial product Adper Single Bond 2 to evaluate the performance in terms of bond strength property among products. At the time of incorporating chitosan, 
or other materials into the adhesive system, the $\mathrm{pH}$ must be acid, because chitosan is insoluble at $\mathrm{pH}$ values higher than 7.0 (basic mean) and extremely soluble in an acid medium. Adper Single Bond 2 and the experimental adhesive system present a $\mathrm{pH}$ around $4.5[21,30]$, which facilitate the incorporation of chitosan. The study of Elsaka [21] tested the bond strength and $\mathrm{pH}$ of adhesives containing different concentrations of chitosan $(0.12 \%, 0.25 \%, 0.5 \%$ and $1 \%)$, observing that the lower the $\mathrm{pH}$, the higher the concentration of chitosan, and that there was a reduction in bond strength with the increase in the concentration of the product. They observed that the majority of fractures were mixed and cohesive in resin, therefore recommending a low concentration of chitosan. In spite of the present study having presented an increase in cohesive fractures in resin with the increase in chitosan concentration, the highest percentage of fractures occurred in cohesive failures in dentin.

The null hypothesis of this study was accepted since no significant differences were observed among groups. These results can be attributed to the similarity in composition and bond strategy among the adhesive materials tested, regardless of the incorporation of chitosan in different concentrations, providing adequate bond to the substrate. In agreement with the present study, Elsaka and Elnaghy [31] added $0.03 \%, 0.06 \%, 0.12 \%$ and $0.25 \%$ of chitosan to a self-etching adhesive system and observed that there was no significant effect on the bond strength values. However, the majority of the fractures found were adhesive, which is in disagreement with the present study, and may be justified by the type of adhesive used, in which the self-etching adhesive presented lower bond strength values when compared with the conventional type [28].
When chitosan was incorporated into the adhesive system, an analysis by electron microscopy showed a deposition of polysaccharides on the dentin surface, covering and filling the dentinal tubules. This promoted electrolytic interaction between the adhesive containing chitosan and the organic component of the tooth at the tooth/restoration interface, and was present from the tooth/restoration interface, penetrating up $100 \mu \mathrm{m}$ into dentin [32]. Moreover, the incorporation of chitosan into the adhesive did not appear to influence the immediate bond strength of the material, when compared with the control group, as was observed in the present study. However, after aging simulated by thermal cycling, bond strength stability was observed in the adhesive containing chitosan, and a reduction of $30 \%$ in bond strength in the specimens in which the adhesive system without chitosan was used. This was explained by the presence of a chemical link by means of covalent bonds between the adhesive containing chitosan and resin, and a physical bond to the organic part of dentin through electrostatic interactions, thus increasing the stability of the link and the hybrid layer [22].

According to the results, the null hypothesis of the present study was accepted, provided that chitosan was used at the concentration of $0.2 \%$ or $0.5 \%$. Nevertheless, the authors recommend that further studies should be conducted to explore the micromorphology at the bond interface, physical and chemical properties of the adhesive incorporated, and the stability of the hybrid layer over the course of time, in addition to considering changes in the chitosan concentration.

\section{CONCLUSION}

It was concluded that the addition of 0.2 or $0.5 \%$ of chitosan into an experimental two-step etch-and-rinse adhesive system had no influence on the bond strength to dentin as compared to a commercial two-step adhesive system. 


\section{REFERENCES}

1. Carvalho RM, Pegoraro TA, Tay FR, Pegoraro LF, Silva NRFA, Pashley DH. Adhesive permeability affects coupling of resin cements that utilise self-etching primers to dentine. J Dent. 2004 Jan;32(1):55-65.

2. Pashley D, Tay FR. Aggressiveness of contemporary self-etching adhesives. Part II: Etching effects on unground enamel. Dent Mater. 2001 Sep;17(5):430-44.

3. Pashley DH, Sano H, Ciucchi B, Yoshiyama M, Carvalho RM. Adhesion testing of dentin bonding agents: a review. Dent Mater. 1995 Mar;11(2):117-25.

4. Pashley DH, Carvalho RM, Sano H, Nakajima M, Yoshiyama M, Shono Y, et al. The microtensile bond test: a review. J Adhes Dent. 1999 Winter;1(4):299-309.

5. Frankenberger R, Tay FR. Self-etch vs etch-and-rinse adhesives: effect of thermo-mechanical fatigue loading on marginal quality of bonded resin composite restorations. Dent Mater. 2005 May;21(5):397-412.

6. Szczepanska J, Pawlowska E, Synowiec E, Czarny P, Rekas M, Blasiak J, et al. Protective effect of chitosan oligosaccharide lactate against DNA double-strand breaks induced by a model methacrylate dental adhesive. Med Sci Monit. 2011 Aug;17(8):201-8.

7. Geurtsen W. Biocompatibility of resin-modified filling materials. Crit Rev Oral Biol Med. 2000;11(3):333-55.

8. Pawlowska E, Poplawski T, Ksiazek D, Szczepanska J, Blasiak J. Genotoxicity and cytotoxicity of 2-hydroxyethyl methacrylate. Mutat Res. 2010 Feb;696(2):122-9.

9. Chang MC1, Lin LD, Chuang FH, Chan CP, Wang TM, Lee JJ, et al. Carboxylesterase expression in human dental pulp cells: Role in regulation of BisGMA-induced prostanoid production and cytotoxicity. Acta Biomater. 2012 Mar;8(3):1380-7.

10. Rabea El, Badawy ME, Stevens CV, Smagghe G, Steurbaut W. Chitosan as antimicrobial agent: applications and mode of action. Biomacromolecules. 2003 Nov-Dec;4(6):1457-65.

11. Francesko A, Tzanov T. Chitin, chitosan and derivatives for wound healing and tissue engineering. Adv Biochem Eng Biotechnol. 2011;125:1-27. doi: 10.10007/10_2010_93.

12. Arancibia R, Maturana C, Silva D, Tobar N, Tapia C, Salazar JC, et al Effects of chitosan particles in periodontal pathogens and gingival fibroblasts. J Dent Res. 2013 Aug;92(8):740-5.

13. Gao S, Hein S, Dagnæs-Hansen F, Weyer K, Yang C, Nielsen R, et al. Megalin-mediated specific uptake of chitosan/siRNA nanoparticles in mouse kidney proximal tubule epithelial cells enables AQP1 gene silencing. Theranostics. 2014 Aug;4(10):1039-51.

14. Costa EM, Silva S, Pina C, Tavaria FK, Pintado MM. Evaluation and insights into chitosan antimicrobial activity against anaerobic oral pathogens. Anaerobe. 2012 Jun;18(3):305-9.

15. Sarasam AR, Brown P, Khajotia SS, Dmytryk JJ, Madihally SV. Antibacterial activity of chitosan-based matrices on oral pathogens. J Mater Sci Mater Med. 2008 Mar;19(3):1083-90.

16. Abraham D, Thomas AM, Chopra S, Koshy S. A comparative evaluation of microleakage of glass ionomer cement and chitosanmodified glass ionomer cement: an in vitro study. Int J Clin Pediatr Dent. 2014 Jan;7(1):6-10

17. Saker S, Alnazzawi A, Ozcan M. Adhesive strength of self-adhesive resins to lithium disilicate ceramic and dentin: effect of dentin chelating agents. Odontology. 2016 Jan;104(1):53-9.

18. Perchyonok VT, Grobler SR, Zhang S. IPNs from cyclodextrin:chitosan antioxidants: bonding, bio-adhesion, antioxidant capacity and drug release. J Funct Biomater. 2014 Sep;5(3):183-96.

19. Arends J, Stokroos I, Jongebloed WG, Ruben J. The diameter of dentinal tubules in human coronal dentine after demineralization and air drying. A combined light microscopy and SEM study. Caries Res. 1995;29(2):118-21.

20. Linden LA, Rabek J. Structures and mechanisms of formation of poly(acrylic acid)-iron(II and III)chloride gels in water and hydrogen peroxide. J Appl Polymer Sci. 1993;50:1331-41.

21. Elsaka SE. Antibacterial activity and adhesive properties of a chitosan-containing dental adhesive. Quintessence Int. 2012 JulAug;43(7):603-13.

22. Diolosà M, Donati I, Turco G, Cadenaro M, Di Lenarda R, Breschi $\mathrm{L}$, et al. Use of methacrylate-modified chitosan to increase the durability of dentine bonding systems. Biomacromolecules. 2014 Dec;8(12):4606-13.

23. Kim YK, Min BK, Son JS, Kim KH, Kwon TY. Influence of different drying methods on microtensile bond strength of self-adhesive resin cements to dentin. Acta Odontol Scand. 2014 Nov;72(8):95462.

24. Wanachottrakul N, Chotigeat W, Kedjarune-Leggat U. Effect of novel chitosan-fluoroaluminosilicate resin modified glass ionomer cement supplemented with translationally controlled tumor protein on pulp cells. J Mater Sci Mater Med. 2014 Apr;25(4):1077-8.

25. Ibrahim MA, Neo J, Esguerra RJ, Fawzy AS. Characterization of antibacterial and adhesion properties of chitosan-modified glass ionomer cement. J Biomater Appl. 2015 0ct;30(4):409-19.

26. Cavalcanti AN, Mitsui FH, Lima AF, Mathias P, Marchi GM. Evaluation of dentin hardness and bond strength at different walls of class II preparations. J Adhes Dent. 2010 Jun;12(3):183-8.

27. Scherrer SS, Cesar PF, Swain MV. Direct comparison of the bond strength results of the different test methods: A critical literature review. Dent Mater. 2010 Feb;26(2):e78-93.

28. Perdigão J, Gomes G, Gondo R, Fundingsland JW. In vitro bonding performance of all-in-one adhesives. Part I -- microtensile bond strengths. J Adhes Dent. 2006 Dec;8(6):367-73.

29. Daneshkazemi A, Davari A, Akbari MJ, Davoudi A, Badrian H. Effects of thermal and mechanical load cycling on the dentin microtensile bond strength of Single Bond-2. J Int Oral Health. 2015 Aug;7(8):9-13.

30. Amim S, Shetty HK, Varma RV, Amim V, Nair PMS. Comparative evaluation of antibacterial activity of total-etch and self-etch adhesive systems: An ex vitro study. J Conserv Dent. 2014 May;17(3):266-70. 
31. Elsaka S, Elnaghy A. Effect of addition of chitosan to self-etching primer: antibacterial activity and push-out bond strength to radicular dentin. J Biomed Res. 2012 Jul;24(4):288-94.
32. Silva PV, Guedes DF, Nakadi FV, Pécora JD, Cruz-Filho AM. Chitosan: a new solution for removal of smear layer after root canal instrumentation. Int Endod J. 2013 Apr;46(4):332-8.

Profa. Dra. Roberta Tarkany Basting

(Corresponding address)

Faculdade de Odontologia e Centro de Pesquisas São

Leopoldo Mandic

Departamento de Odontologia Restauradora -

Dentística

Rua José Rocha Junqueira, 13, Bairro Swift,

Campinas/ SP, CEP: 13045-755, BRAZIL

Date submitted: 2017 Aug 25

E-mail: rbasting@yahoo.com

Accept submission: 2017 0ct 03 